\title{
Lazy or Dyslexic: A Multisensory Approach to Face English Language Learning Difficulties
}

\author{
Yanilis Romero ${ }^{1,2}$ \\ ${ }^{1}$ Institución Educativa Antonia Santos, Montería, Córdoba, Colombia \\ ${ }^{2}$ Universidad del Norte, Barranquilla, Atlantico, Colombia \\ Correspondence: Yanilis Romero, Cra 32 \# 35-09 Urbanización Mi Refugio, Montería, Córdoba, Colombia. \\ Received: March 25, 2020 \\ Accepted: April 18, 2020 \\ Online Published: April 21, 2020 \\ doi: 10.5539/elt.v13n5p34 \\ URL: https://doi.org/10.5539/elt.v13n5p34
}

\begin{abstract}
An investigation was conducted to help weak academic English learners in a public high school in Colombia, as they seemed to be facing a learning specific difficulty called dyslexia. A focus group of ten students from ninth and tenth grade was the beneficiaries of the design, implementation, and assessment of five multisensory activities to help students decrease their struggles while learning the foreign language (English). For the present action research, five activities were applied during two academic terms (six months) where students were taught verbs, grammar rules, question words, and minimal pairs to help them do better while reading. Outcomes showed that low academic students tend to have a better performance when teachers target multisensory activities to assist them in their learning process related to grammar within the English sessions. Color-coded activities help low achieving students to exercise and remember more easily as senses are engaged while learning, reading exercises are better approached if their workload is split into smaller quantities compare to regular learners.
\end{abstract}

Keywords: dyslexia, low academic performance, multisensory activities

\section{Introduction}

In Colombia, the teaching of a foreign language (L2) such as English in most public schools starts when a child reaches the sixth grade and continues until the eleventh. In other words, a student has six years of school instruction within which to learn a foreign language. This seems to be a reasonable amount of time to effectively master the language, but most learners end up with only a basic level of English while others do not even reach the minimum goal (Ministry of Education, 2016). The process of learning a foreign language needs to be a joyful experience where students and teachers feel empowered and enthusiastic. However, it is common knowledge that not all students in a classroom are interested in learning English and there could be a great number of reasons why: the methodology, the time, the type of activities, and even the kind of teacher. When having uninterested learners, teacher's thinking might run to perceive "those learners are lazy", or simply "do not like the subject". It is uncommon that some teachers feel invited to analyze why some students seem reluctant to learn something that other learners consider easy to handle.

In the case of English, educators (mostly in public schools) teach schoolchildren grammar and skills to enable them to learn English as a language that will eventually be used to communicate ideas. However, when instructing them, there is little awareness of the possible specific learning differences and the special needs of students, as the planning of a class is just one for the whole class. That is why not all lessons are effective for the hundred percent of students as there might be pupils whose performance is affected by a learning disorder. For instance, dyslexia, which is one specific learning difference that is not easily perceived at school or home. Dyslexia can be easily disguised with silence and poor performance which might be confused with laziness or reluctance.

Approximately $21,6 \%$ of students between seven and eleven have learning difficulties (Gallo, 2017). This number might seem to be meaningless but in a school with 2200 students, the amount becomes significant. Students targeted with dyslexia need extra help while learning and teachers need to provide it. Unfortunately, the current Colombian government does not provide any special assistance for students with specific learning differences, and most of them are taught under the same methods. Currently, Colombian public schools lack specialists who can diagnose dyslexia in students' mother tongue. Such circumstances worsen the reality for these 
learners dealing with a foreign language. Within educational centers, there is no help for dyslexic children to be guided through a medical path to overcome the need. The complexity of the situation needs teachers to increase their awareness to find ways to promote assertive foreign language learning for those students in need.

The purpose of this research was to design, implement and analyse a series of multisensory activities to provide a focal group of ten low academic performing students with an engaging learning environment to improve their English academic performance.

\section{Literature Review}

This study based the definition of dyslexia taken from the new Diagnostic and Statistical Manual of Mental Illnesses (DSM-V) compared to the DSM-IV (American Association of Psychiatry, 1998) conceptualizes it as a specific disorder of reading learning, which includes slow reading speed, and difficulties in understanding texts. Another definition underlying this proposal is that dyslexia can be described as a language-based learning disability, from the severity of reading, writing, and spelling (Elbeheri, 2006). Subsequently, other definitions of dyslexia are provided though the concept adopted by this study is the one given by the American Association of Psychiatry in 1998 stated above.

\subsection{What is Dyslexia}

Dyslexia can have several definitions depending on the group of academics/specialists who argument knowledge on the subject, indeed the concept of dyslexia varies from being a condition to a completely diagnosed illness with symptoms.

Some of these concepts include:

The Research Group on Developmental Dyslexia of the World Federation of Neurology in 1996 stated that dyslexia are: "a disorder manifested by difficulty in learning to read despite conventional instruction, adequate intelligence, and sociocultural opportunity. It depends on fundamental cognitive disabilities, which are frequently constitutional in origin" (Ott 1997, pg. 3).

In 1995 Lyon stated dyslexia as "one of several distinct learning disabilities. It is a specific language-based disorder of constitutional origin characterized by difficulties in single word decoding, usually reflecting insufficient phonological processing." (page 4). That is to say that dyslexia are closely related to language learning, which means that reading and comprehension of written texts can be implicated.

Lyon (2003) offered an updated concept acknowledging that dyslexia has evolved since the last time he addressed the issue. In 2003 he stated that "Dyslexia is a specific learning disability that is neurobiological in origin. It is characterized by difficulties with accurate and/or fluent word recognition and by poor spelling and decoding abilities". (Lyon, 2003, pag:)

Because of the multiple definitions of dyslexia nowadays, this study will adopt the definition as stated by the International Dyslexia Association (IDA) which argues that "Dyslexia is a language-based learning disability. Dyslexia refers to a cluster of symptoms, which result in people having difficulties with specific language skills, particularly Reading". This conceptualization allowed us to play with the proposal of different multisensory games to better address the target students' needs. Given that dyslexia are characterized by a reading problem and that according to Guzmán (2007) in Colombia there are 60\% with reading and writing problems, it is possible to think that said population is afflicted by dyslexia disorder, but what to do? To meet the needs of students with dyslexia disorder a decade ago, a model called "The Orton-Gillingham (OG)" was designed, which is a multisensory instructional model characterized by learning that uses the visual, auditory, tactics and kinesthetic (Ritchey \& Goeke, 2006). Currently, this model can be implemented with adaptations and adjustments to determine its effectiveness once teachers in Córdoba know their proper execution. It should be noted that this model has been a benchmark for research over the last decades in developed countries. Some of these investigations revealed the importance of the use of the senses in the teaching of literacy. Investigators Simpson, Swanson, et al (1992) conducted studies with juvenile offenders, instructing them only 45 minutes twice a week in their house arrest. Positive results were reported from this study where the focus group obtained significant gains in reading.

\subsection{Dyslexia in English Language Teaching and Learning}

Since dyslexia is a condition that affects language processes (learning) it might be complex to address if a person with dyslexia is forced into an educational system that encompasses students with varying abilities in the same pattern of teaching and learning. 
Some of the main underpinnings' scholars have released in terms of foreign language learning for dyslexic students has to do with the fact that the nature of the disability itself does not quite help learners to deal with written texts effectively. Another key factor is related to the teaching methods teachers use once they are in the classroom (Schneider, 2009). The aforementioned factors might have great repercussions in the foreign language learning of dyslexic students as their foreign language opportunities should be shaped differently due to their condition. Ott (1997) claimed that dyslexic students might not be good learners of foreign languages since they can "make stumbling attempts at gaining proficiency with a second language" (pg.187).

In this sense, teachers' role recovers great importance as learning opportunities for dyslexic students need to be provided differently.

\subsection{Multisensory Model}

In 1994, Dooley proposed a new model called Multisensory Integrated Reading and Composition (MIRC) for high school students, which was based on teaching reading and writing through multisensory strategies. The model was welcomed with positive impact demonstrating that the students treated with it had significant gains in terms of text comprehension. Oakland, Black, et all (1998) examined the OG-model based on a remedy program known as Dyslexia Training Program (DTP) in which a comparative study of instruction was made through the teacher and others through video. The results of an intervention group and a control group were analyzed showing that the experimental group obtained better performance in terms of text comprehension and reading production. Existing models with a multisensory approach have been effective in other contexts. This research proposes the design of multisensory activities effectively help learners learn new vocabulary, understand some grammar rules and gain strategies that can be helpful when dealing with reading comprehension texts. Multisensory activities provide a pedagogical framework that contributes to the development of skills and learning chances.

\section{Method}

\subsection{Research Design}

The current investigation is qualitative and emerged from observational processes carried out in different groups of ninth and tenth graders at Antonia Santos School in Monteria. Students' lack of motivation and low production and performance in the English subject were two issues detected to be affecting the students' academic performance. Since the main reason that prompted the genesis of this research was the concern of a great number of students facing difficulties while learning English, a reflective process was carried out to design, analyze and evaluate a set of strategies related to the teaching and learning of this foreign language. The set of strategies designed consisted of five different multisensory activities. Bearing in mind the aforementioned, this study fits into the action research approach because it was based on a classroom intervention carried out by two English teachers to propose a possible solution to attend a particular issue that was taking place in the classroom. As Nunan and Bailey (2009, p.227) state: "action research represents a particular stance...in which the practitioner is engaged in critical reflections, on ideas, the informed application and experimentation of ideas in practice, and the critical evaluation of the outcomes". For this particular case, the reflection, the experimentation, and the critical evaluation were carried out with a focus group of 10 students from Antonia Santos high School. Kemmis and McTaggart (1994) also expressed that Action Research refers to a cycle of actions that teachers as researchers can take in order to improve their practice. The ultimate purpose of this research is to propose a possible solution into a context after going through a cycle of successive arrangements to help learners as well as the teacher to have a positive impact in students' English learning process. 


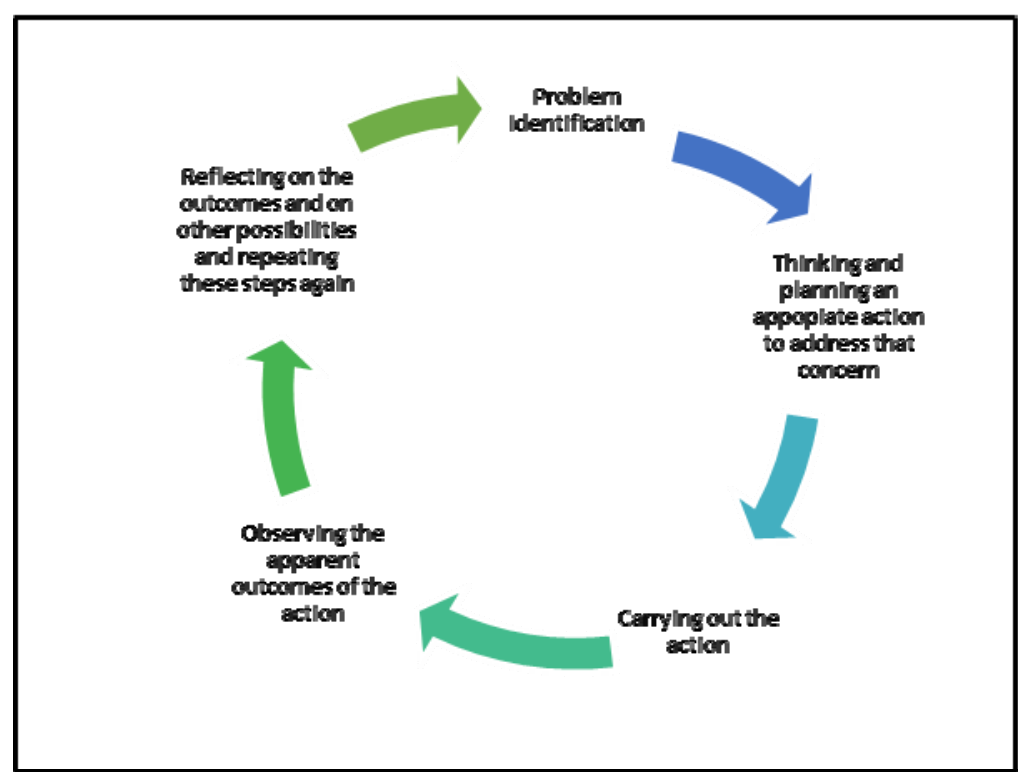

Figure 1. Action Research Nunan \& Bailey, 2009

Figure 1 above shows the process taken to spark this investigation. In the problem identification: It was possible to find students' poor academic performance and the possible cause (Dyslexia). In the thinking and planning stage, the researcher took students' viewpoints to design the multisensory activities based on learners needs and proposed the activities. In the third cycle the set of multisensory activities were implemented and the apparent outcomes of the actions are being reported while the final reflections are being considered to eventually proceed and start the cycle over and keep improving students' academic performance as well as their learning processes. The action research method in this piece of work helped the teacher to operationalized a plan and evaluate the effects of the plan over the teaching and learning process of the target population.

\subsection{Context and Participants}

This research project was implemented in a public school called Antonia Santos. This school is located in Monteria, Colombia. It is 52 years old and has gradually developed during the last 20 years. Nowadays Antonia Santos includes all levels of education: nursery, primary, secondary and high school. The current population of the school is approximately 2200 students coming from low-income families in the south of the city.

Currently, Antonia Santos complies with the requirements demanded by the Colombian Ministry of Education and as a result, it has been twice awarded national recognition as an ongoing developing school due to the progress it has recently shown. Since 2014, the national government has been trying to ensure inclusive education for students countrywide. However, these efforts have had little or no success with students with specific learning differences since all of them are taught in the same way and there are no differentiated instructions for those kids who struggle with different subjects including English as a foreign language. The majority of learners have little access to study resources, hence, public schools must become a safe place where it is ensured that students can learn, gain and share knowledge. Antonia Santos was chosen for this study because of the organized processes they have and its positive attitude to welcome projects to transform teachers' practicum.

For this study, a focal group of 10 students (two girls and eight boys), whose ages ranged between 14 and 16, were chosen under the parameter of being considered uninterested to learn English as a foreign language. From the target population, four of them were students who have formerly failed the previous grade (repeaters). To select the 10 students that would be part of the focus group, a user-friendly written checklist identified students who struggle while learning, was provided to other teachers.

\subsection{Researchers' Role}

The role as a researcher is described by Burns (1999) cited in Valencia (2012, p.28) who summarizes the researcher's role as follows: "the researcher investigates questions in a systematized way, collects and analyzes data including his own observations and reflections, articulating theories, discussing his research with some colleagues to validate his findings and data interpretations". 
Throughout this study, the researcher played several roles. Firstly, the researcher was a participant observer who identified classroom problems by collecting data to formulate a research question. Secondly, the researcher's role turned into a planner and a designer of the activities to be used during the intervention, and responsible for guiding the students to get along with the activities designed. In the following stage, the role of the researcher changed becoming facilitator and mediator, who provided the necessary input and support for the successful use of the handouts in the implementation. In the final stage, the researcher compiled all the data collected to draw conclusions and provide an answer to the research question bearing in mind, not just the data gathered through the intervention process, but comparing and articulating personal findings with previous studies and the literature available.

\subsection{Data Collection Instruments and Procedures}

To gather data for this research project, three classroom observations with a duration of 120 minutes each, three informal interviews carried in Spanish and five sets of multisensory activities were used to elicit relevant information. Before and after using the multisensory activities, students from the ninth and tenth graders groups were randomly selected to be interviewed. The purpose of these informal interviews was to gather useful information for the future design and implementation of the multisensory sets. Interviews (five) made while the intervention process had the purpose to assess the impact of the use of multisensory activities and how to improve the activities to passive effects on future learners. During the intervention stage, five sets of multisensory card-activities were carefully designed taking into account the observation process and the information obtained through the informal interviews that took place before the intervention. During a time of six months, the learners had to use the cards to work on different tasks.

The validity of the vocabulary quizzes used in the intervention process was verified by enclosing the design to point out the objectives proposed and the purpose of providing the focus group of 10 possible dyslexic students with an engaging learning environment. Three steps were developed during the research study. The first step consisted of, a reflective process developed by the researchers acting as participant observers having opportunities to reflect on the difficulties of the students chosen in regards to their learning process. This reflection and observation process was complemented by some data gathered through five informal interviews held with some of the participants.

During the second step, five sets of multisensory activities were designed and applied for the pedagogical intervention. The analysis that could be drawn from the use of these activities provided useful information that was used later in the analysis and reports that emerged from this project. In the last step, the researchers had the opportunity to reflect and continue doing a deeper analysis of the impact on working with multisensory activities to improve learning English as a foreign language. During this step, five informal interviews took place to listen to the opinion that the students had after being exposed to this dynamic of learning.

\subsection{Design and Validation of Instruments and Procedures}

In any study, it is important to revise the tools that are used to gather and evaluate the data. To validate the instruments, it is necessary to verify whether the tools elicit the information for which they were mainly designed to. To achieve this, all the instruments used in the research (interviews, checklist referral, and multisensory activities) were carefully revised to assure reliability and validity. Preliminary data was gathered through observation and informal interviews with some of the participants, which unfolded learners the opportunities to express their learning-preferences and their learning difficulties, among other relevant aspects. Furthermore, in the intervention stage, English learning was tested through some reading comprehension exercises after the use of some multisensory activities. Finally, informal post interviews were applied to the participants to allow them to state their opinions and views on the use of multisensory activities and their possible progress after the implementation of the project.

\section{Results}

This research project prompted to design and implement a series of multisensory activities, to provide a focus group of ten dyslexic students with an engaging learning environment to improve their english academic reading academic outcomes.

A chronogram was followed to carry out the process of the action research method in the cycles of planning where it was possible to design of multisensory activities, the implementation cycle where the teacher-researcher used of the activities while observing the deceptive changes and finally the analysis or reflection cycle. In each stage, some tools were used to gather different types of data. See Table 1 below: 
Table 1. Pedagogical Intervention and Implementation

\begin{tabular}{|c|c|c|}
\hline Stage & Time length & Activity \\
\hline \multirow{2}{*}{$\begin{array}{c}\text { Design of multisensory } \\
\text { activities }\end{array}$} & 2 weeks & $\begin{array}{l}\text {-Selection of students: Teachers refer } \\
\text { students to the project. Observation (see } \\
\text { appendix 1) and use of a checklist (see } \\
\text { appendix 2) } \\
\text {-Interview with the students: The purpose of } \\
\text { this interview was to identify what type of } \\
\text { activities were best to address students' } \\
\text { needs (see appendix } 3 \text { ). }\end{array}$ \\
\hline & 2 weeks & $\begin{array}{l}\text {-Analysis of the interviews: Studying } \\
\text { students' responses and decide the type of } \\
\text { activities to design. } \\
\text { - Designing of activities: Vocabulary (time } \\
\text { markers, wh-questions) Phonology/ } \\
\text { pronunciation (Minimal pairs). } \\
\text { Grammar/verb Pictionary }\end{array}$ \\
\hline \multirow{3}{*}{$\begin{array}{l}\text { Implementation of the } 5 \\
\text { sets of multisensory } \\
\text { activities }\end{array}$} & 4 weeks & $\begin{array}{l}\text { English sessions: Implementation of verbs } \\
\text { and wh-words (See appendix 2). Reading } \\
\text { exercises to practice the lexis learned. } \\
\text { Evidence: Assessment of reading activities } \\
\text { and comprehension questions }\end{array}$ \\
\hline & 4 weeks & $\begin{array}{l}\text { English sessions: Use of minimal pairs to } \\
\text { reinforce sounds, teach homophones and } \\
\text { meaning. Color-coded pairs. } \\
\text { Evidence: Assessment of reading out loud } \\
\text { passages, lines or a paragraph }\end{array}$ \\
\hline & 4 weeks & $\begin{array}{l}\text { English sessions: Teaching of time markers } \\
\text { and differencing verb tenses. } \\
\text { Evidence: Assessment of reading exercises } \\
\text { with different grammar tenses }\end{array}$ \\
\hline \multirow[b]{2}{*}{$\begin{array}{l}\text { Analysis of the } \\
\text { effectiveness of } \\
\text { multisensory games }\end{array}$} & 4 weeks & $\begin{array}{l}\text { Use of real-like images to describe } \\
\text { situations. To label them according to a short } \\
\text { text. Organize pictures accordingly. }\end{array}$ \\
\hline & 4 weeks & $\begin{array}{l}\text { Analysis data and students' academic } \\
\text { performance (card reports from school) } \\
\text { Interviews: With students and parents. } \\
\text { Assessing effectiveness }\end{array}$ \\
\hline
\end{tabular}

Note: Columns are describing the stage, the time and the activities carried out during the research cycle of the research.

Each phase described in the table above gives an account of the period invested in each of the action research cycle presented by the research. 
To nurture the phase of thinking and planning 10 randomly-chosen students from three groups of ninth and two of tenth respectively were interviewed with interview \# 1 (See appendix 1). From which was seen, that 9 out of ten manifested to like the English class. Regarding the activities, students revealed to like the activities proposed by the teacher in the foreign language sessions. In terms of academic performance, only half of the sample said they were doing well in the English class, unknown were the reason why others said their achievement in the class was regular. Despite this, no one admitted to having problems with the class, the idea of having $50 \%$ of them saying they felt not good students seemed to be critical. Concerning the activities and aspects of the language, students wanted to improve, eight of them marked: vocabulary related to wh-words, verbs use and time markers. Others (2) chose grammar: use of third person and adverbs. The skills of the language, interviewees stated wanted to hinder were reading and some pronunciation.

As a result, the sets of multisensory cards were designed to closely relate to what the interview unfolded with the needs of the students. The activities needed to be multisensory, where the use of hands, ears and other senses. To offer broader lenses to understand the activities and the way they were used, see the description below.

\subsection{Activity \#1 Wh-words}

Description of the activity: ten cards containing wh-words were designed. The front part had the word in English and the backside had the meaning in Spanish. This activity was implemented during the foreign language class twice a week. The tutor had the opportunity to offer to the target population an exploratory session of the material before it was used in class. Then, involved students were paired up to work (ask and answer verbs and meaning) with the cards. Each of them had a set of their own.

\subsection{Activity \# 2 Verbs}

Thirty was the number of verbs that the research project proposed for the target learners. Verbs were illustrated to facilitate students' learning process. The teacher explained the pronunciation as well as the usage, assisted by motions to promote the use of ears, eyes, mouth. This type of execution allowed the learner to use the senses. Students had to study verbs three times a week and use the set of cards while English was taught.

\subsection{Activity \# 3 Time Markers}

Twelve time-markers were chosen to help learners distinguish among sentences or phrases written in the present, past, and future. These time markers were color-coded in black, yellow and red. The color was not exactly matched with the tense (present/past/future) but related to a category to easily remember this lexis. Interestingly, when using time markers twice a week, learners could also state verbs in the past and present mostly. The technique of the activity was to pair students up, in other words, in pairs students got to ask and answer, what was the meaning, plus the tense of the expression.

\subsection{Activity \# 4 Minimal Pairs}

To strengthen some pronunciation, ten sets of minimal pairs were designed with the purpose to reinforce some vowel sound similarities and differences when pronouncing words. The activity proposed learners to repeat sounds. Learn how to distinguish between each set. Each of the two words is given a number: one (1) or two (2). Learners had to say one (1) or two (2) once they heard the word, the teacher pronounced. This activity required learners to train their ears to identify the words, show fingers indicating the quantity according to the sound they thought the teacher said. The frequency of the implementation of this activity was twice a week.

\subsection{Activity \# 5 Real-like Images}

Ten images were printed from local pictures taken by the researcher. The images showed a familiar context where the colors, faces and landscape was related to students' reality. The use of the pictures in the proposed activity was for learners to describe what they saw, or what they thought what people or things in the photo would do in the future or the past. Every student had the opportunity to describe a different picture in every encounter (three times a week). The teacher made corrections if the students made mistakes. During the last week of the implementation of this activity, while one student was describing the pictures, others were writing or trying to write complete sentences from what they heard in the description.

It is important to highlight that during the pedagogical intervention, the teacher played the role of facilitator, guide, and manager of the multisensory activities, supporting the students in the different needs they could have to use effectively and have fun when using the sets of multisensory sets of cards and activities. The teacher's role is in correspondence with the action research method proposed in the piece of work. 


\section{Discussion}

Highlights from the implementation of this research project unfold the idea that low academic students tend to have a better performance when teachers target multisensory activities to assist them in their learning process related to grammar within the English sessions. Evidence was exposed when four of the five participants manifested while being interviewed that learning the verbs and their use aided them to do better in the English sessions. Fact that evidently showed a progress in their english academic performance. The feeling of achievement came back to the learners when they could recognize verbs, sounds and the words that facilitate their understanding of what the tutor was teaching about. A contrary fact of what was taking place at first when the observations were made.

During the cycle of problem identification, it was perceived that the teacher prepared one single activity, which involved basic instruction and long texts. During this stage, an uninterested attitude towards the English language learning was also noticed, despite students' manifestation of a good taste for the class. The cycle of implementation shed to light that students in this study were not lazy but possibly mistreated under the idea that the former teaching process needed no adjustments but students needed a change of attitude.

With regards to color-coded activities, they helped low achieving students to exercise and remember more easily as senses were engaged while learning. In other words, if learners are engaged within an environment that allows them to use hearing, speech, touch, sight, it is more likely that learners enjoy what they are learning. As a result, their attitude and mood would be positive when approaching the lessons as well as the activities proposed. The aforementioned is stated since all of the learners questioned in the after implementation interview claimed that multisensory activities and colors were helpful for them to learn and to appreciate what they were doing. The previously mentioned fact also revealed that multisensory activities effectively helped learners do better in activities related to reading which contributed to a big portion of students' assertive attitude when lessons were developed. Subsequently, students' academic performance mutated until it became better and motivation raised after the implementation and use of multisensory activities.

Findings while implementing the research exposed that participants better approached reading exercises as their workload was split into smaller quantities compare to regular learners. The fact to unbalance their reading workload for this specific population was discovered as a collateral conclusion when learners stated that they did not like reading activities because of their length. This modification was introduced obeying to the previously indicated gap. The outcomes were positive as these learners improved their results when dealing with academic reading exercises differently proposed by the teacher in the English class.

\section{Conclusions}

Low academic performance students might need extra help when learning a foreign language as their level of achievement could be related to a kind of special learning need called dyslexia. As suggested after the observation phase, the target population chosen had trouble dealing with some learning activities especially the ones related to reading. Some of the causes could be the amount of lexicon they had gained, up to the ninth or tenth grade. Despite this, learners did positive progress after having to use the activities proposed by the research Evidence of this, showed that activities involving more than one sense had a positive impact on the learning of vocabulary related to verbs, wh-words and time markers.

Multisensory activities awaken the senses of poor academic students if they are used to address students' need and become integral part of the teaching and learning process in the English class. Another possible conclusion could be drawn from the fact that learning vocabulary hinders students' attitudes to approach reading activities resulting in better numerical outcomes while the intervention phase of the present research.

The focus group is not proven dyslexic but it was proved that multisensory activities were beneficial to improve students' academic performance while learning a foreign language such as English.

Practical strategies to foster the learning of English seemed to assertively work in scenarios where students gained awareness of what their needs might be and how to cope with their struggles. Hence, another significant gain after implementing multisensory activities was that students could identify their metacognitive strategies to approach learning. 


\section{References}

American Psychiatric Asociación. (1998). Manual diagnóstico y estadístico de los trastornos mentales. (DSM-IV.). Barcelona: Masson Dyslexia. NY: Routledge.

Dooley, B. (1994). Integrando la lectura y la comprensión multisensorial mente. Efectos en los alcances de lectores remediales. Tesis doctoral no publicada. Denton: Texas Women's University

Elbeheri, G., Everatt, J., Reid, G., \& Al-Mannai, H. (2006). Dyslexia Assessment in Arabic. Journal of Research in Special Educational Needs, 6, 143-152. https://doi.org/10.1111/j.1471-3802.2006.00072.x

Gallo, C. (2017). Por los niños con dificultades. 03 de agosto de 2017. Con los anteojos bien puestos. Retrieved from: //blogs.eltiempo.com/anteojos-bienpuestos/2017/08/03/la-dislexia-de-los-congresistas/

Guzmán, R. J. (2007). Colombia, Alfabetización Inicial a través de los Proyectos de Aula en el Marco de la Enseñanza Para la Comprensión. Universidad de la Sabana., Bogota Colombia. Retrieved from: https://www.elcolombiano.com/opinion/columnistas/la-dislexia-en-colombiaMF9722860

Lyon, G.R. (1995). Toward a definition od Dyslexia. Annals of Dyslexia, 45, 3-27. https://doi.org/10.1007/BF02648210

Nunan, D, \& Bailey, K. (2009). Exploring Second Language Classroom Research: A comprehensive guide. Boston: Heinle/CENGAGE learning.

Oakland, T., Black, J. L., Stanford, G., Nussbaum, N. L., \& Balise, R. (1998). An Evaluation of the Dyslexia Training Program: A Multisensory Method for Promoting. https://doi.org/10.1177/002221949803100204

Ott, Philomena. (1997). How to Detect and Manage Dyslexia - A Reference and Resource Manual. Portsmouth: Oxford Blantyre

Ritchey, K., \& Goeke, J. (2006). Orton-gillingham and orton-gillingham based reading instruction: A review of the literature. The Journal of Special Education, 40(3), 171-183. https://doi.org/10.1177/00224669060400030501

Schneider, E. (2009). Dyslexia and foreign language learning. The Routledge Companion to

Simpson, S.B., Swanson, J.M., \& Kunkel, K. (1992). The impact of an intensive multisensory reading program on a population of learning disabled delinquents. Annals of Dyslexia, 42, 54-66. https://doi.org/10.1007/BF02654938

Valencia, E. (2012). Fostering self-efficacy strategies towards Intensive Reading in ten-year old students in a blended English Language Learning Environment. Retrieved May 10th-2017 from http://intellectum.unisabana.edu.co:8080/jspui/handle/10818/3193 


\section{Appendices}

Appendix 1

INSTITUCIÓN EDUCATIVA ANTONIA SANTOS

2016: "CON SENTIDO DE PERTENENCIA, LOGRAMOS LA EXCELENCIA"

MONTERÍA-CÓRDOBA

INSTRUMENTO DE APOYO PARA EL DIAGNÓSTICO ACADÉMICO

INSTRUCTIVO: Apreciado docente, atendiendo a lo observado usted coloque una $\mathrm{X}$ en cada uno de los aspectos.

NOMBRE DEL ESTUDIANTE: GRADO: EDAD:

\begin{tabular}{|c|c|c|c|c|c|}
\hline & ATENCIÓN & NUNCA & $\begin{array}{l}\text { ALGU NAS } \\
\text { VECES }\end{array}$ & $\begin{array}{c}\text { CASI } \\
\text { SIEMPRE }\end{array}$ & SIEMPRE \\
\hline 1 & No termina lo que empieza & & & & \\
\hline 2 & Parece no escuchar & & & & \\
\hline 3 & Se distrae fácilmente & & & & \\
\hline 4 & $\begin{array}{l}\text { Tiene dificultad en concentrarse en el trabajo } \\
\text { escolar o en actividades que requieran atención }\end{array}$ & & & & \\
\hline \multirow[t]{2}{*}{5} & $\begin{array}{l}\text { Tiene dificultad para mantenerse } \\
\text { en juegos }\end{array}$ & & & & \\
\hline & IMPULSIVIDAD & & & & \\
\hline 1 & Actúa sin pensar & & & & \\
\hline 2 & Cambiar de una actividad a otra rápidamente & & & & \\
\hline 3 & $\begin{array}{l}\text { Tiene dificultad para organizar su trabajo motivado } \\
\text { por un impedimento cognositivo }\end{array}$ & & & & \\
\hline 4 & Necesita muchas supervisión & & & & \\
\hline 5 & Interrumpe las clases & & & & \\
\hline \multirow[t]{2}{*}{6} & $\begin{array}{l}\text { Tiene dificultad para esperar su turno durante } \\
\text { juegos y ejercicios en grupo }\end{array}$ & & & & \\
\hline & HIPERACTIVIDAD & & & & \\
\hline 1 & Corre demasiado y se sube sobre las cosas & & & & \\
\hline 2 & $\begin{array}{l}\text { Tiene dificultad para quedarse quieto y está en } \\
\text { continuo movimiento }\end{array}$ & & & & \\
\hline 3 & Tiene dificultad para mantenerse sentado & & & & \\
\hline 4 & $\begin{array}{l}\text { Siempre se está moviendo como si estuviera } \\
\text { impulsado por un motor }\end{array}$ & & & & \\
\hline & COMPORTAMIENTO CON SUS COMPAÑEROS & & & & \\
\hline 1 & Pelea, golpea, etcétera & & & & \\
\hline 2 & No es querido por otros niños & & & & \\
\hline 3 & Suele interrumpir las actividades de sus compañeros & & & & \\
\hline 4 & Es líder, siempre diciéndoles a los demás que hacer & & & & \\
\hline 5 & Molesta y pone apodos a los demás & & & & \\
\hline 6 & Se rehúsa a participar en actividades de grupo & & & & \\
\hline 7 & Se pone de mal genio fácilmente & & & & \\
\hline
\end{tabular}

Tomado de Annie Acevedo. En cómo funciona el cerebro de los niños. 
Appendix 2

Observation sheet

Class: Date: Grade:

$>$ Check and describe

1. Low academic students' performance and behavior

Positive Negative Neutral:

Description:

Check and describe

2. Teachers caring about poor academic students' performance and behavior in class 100: 80: 60: 40: 20:

Description:

\section{Class activities}

Activities are proposed: For everyone: Yes / No Differentiated for some students: Yes / No Are reading comprehension activities proposed in the class: Yes No

Do reading activities have: (Write yes or no)

Images: Photos: Bold words Close questions open questions:

Does the teacher check the comprehension questions: Yes No

How (Please describe)

Description: 
Appendix 3

Interview \#1

This interview applied during the exploratory phase

1. Te gustan las clases de inglés? $\mathrm{Si}$ No Porque?

2. Te gustan las actividades de lectura que propone la clase de inglés?Si No Por qué?

3. Cómo es tu rendimiento académico en inglés?

4. Qué tipo de actividades crees que te ayudarían a trabajar mejor en la clase de inglés? (escoge tres)

a. Vocabulario de preposiciones

b. Vocabulario básico de intereses familiares

c. Gramática, reglas y auxiliares

d. Verbos y su uso

e. Gramática adverbios/ adjetivos/

f. Verbos modales

g. Vocabulario, marcador de tiempo

h. Vocabulario de wh questions

i. Vocabulario de partes de la casa, partes del cuerpo, objetos del salón

j. Gramática: reglas terceras personas

5. Qué aspectos del inglés quisieras mejorar?

k. Habla (Hacer dos o más oraciones en forma oral)

1. Escucha (Entender lo que el profesor dice)

m. Escritura (producción de párrafos cortos)

n. Pronunciación (algunos sonidos de vocales en inglés)

o. Leer (Textos cortos y comprender)

6. Crees que, si te dieran una ayuda extra, mejorarías tus resultados en inglés? 
Appendix 4

Entrevista \#2 (Implementing the project)

1. Has encontrado útil el uso de las actividades de apoyo que te ofrecen extras en la clase de inglés? Sí No

Como:

2. Cuál de todas las tarjetas y de las actividades te ha parecido más útil?

3. Cuál de todas las tarjetas y de las actividades te ha parecido la menos útil?

4. Qué consideras has aprendido mejor gracias a las actividades realizadas con las tarjetas?

Appendix 5

\section{Entrevista \# 3 (After the project)}

1. Crees que es útil ofrecerles a los estudiantes con bajo desempeño actividades de apoyo que en la clase de inglés?

Sí _ No

Como:

2. Crees que si te dan un apoyo adicional durante las actividades de lectura especialmente te iría mejor? Sí No

Como:

3. Qué es lo que más te ha gustado del proyecto?

4. Qué es lo que menos te ha gustado del proyecto? 


\section{Appendix 6}

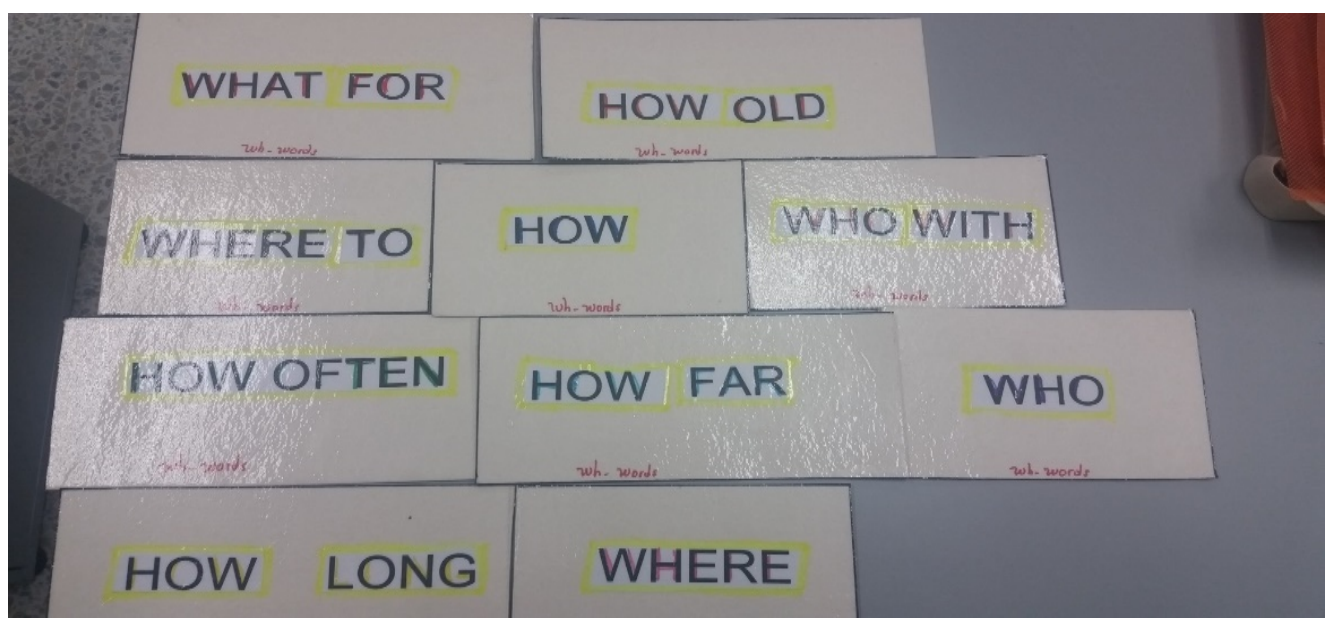

Appendix 7

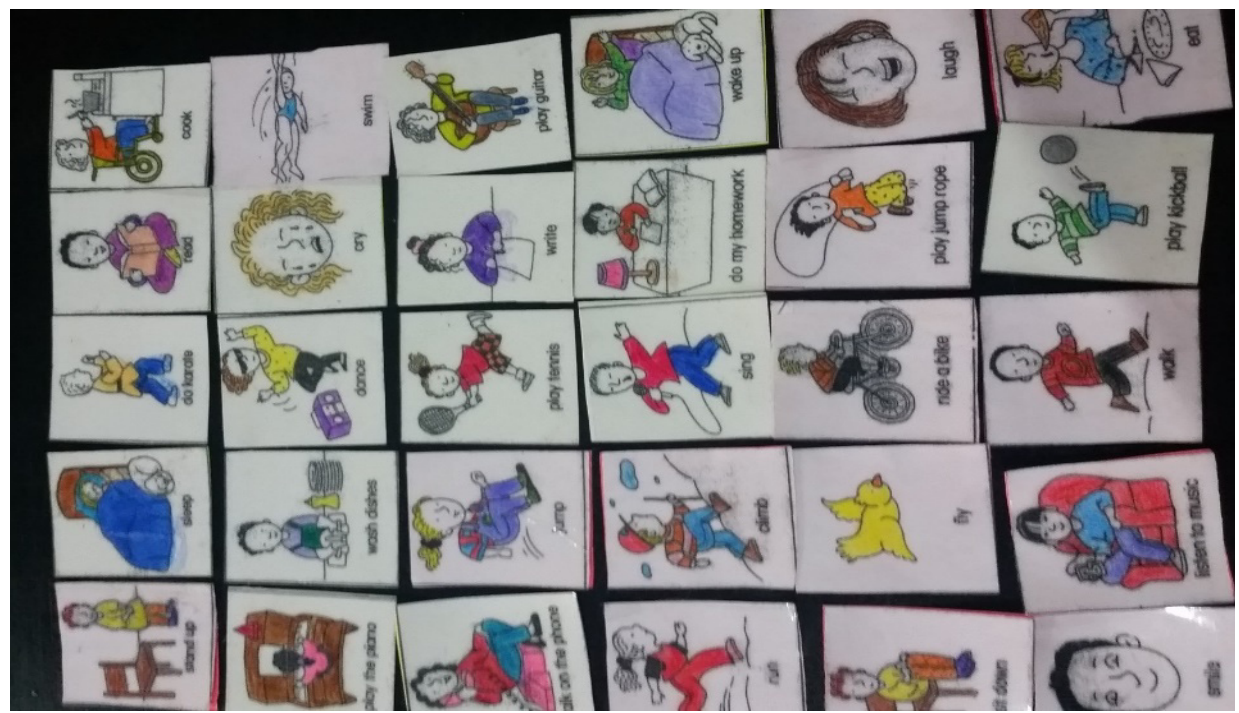

Appendix 8

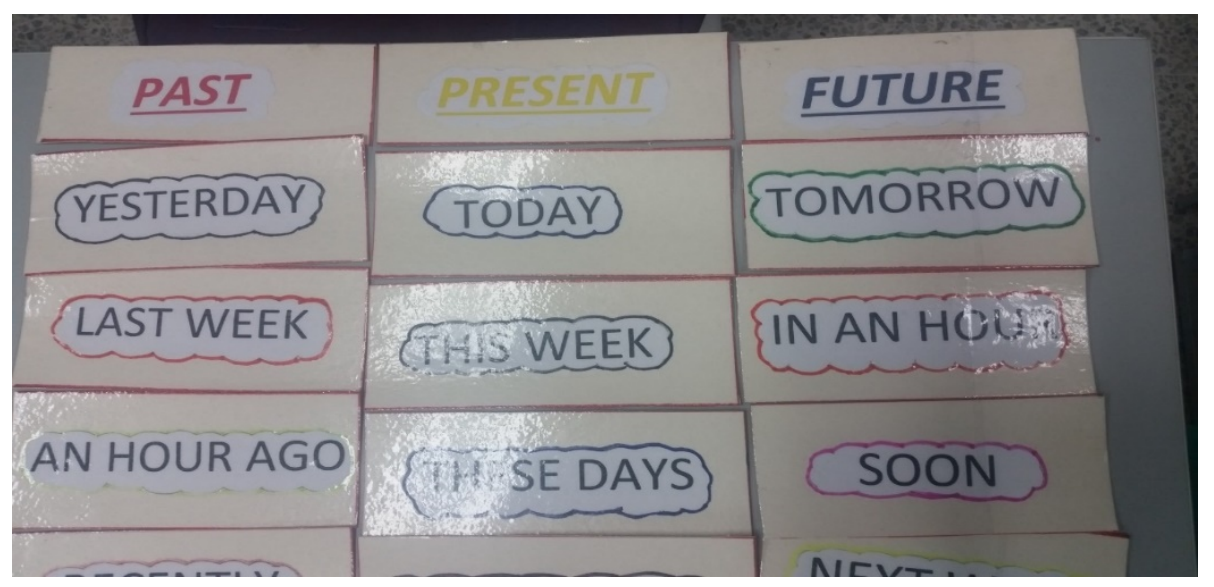


Appendix 9

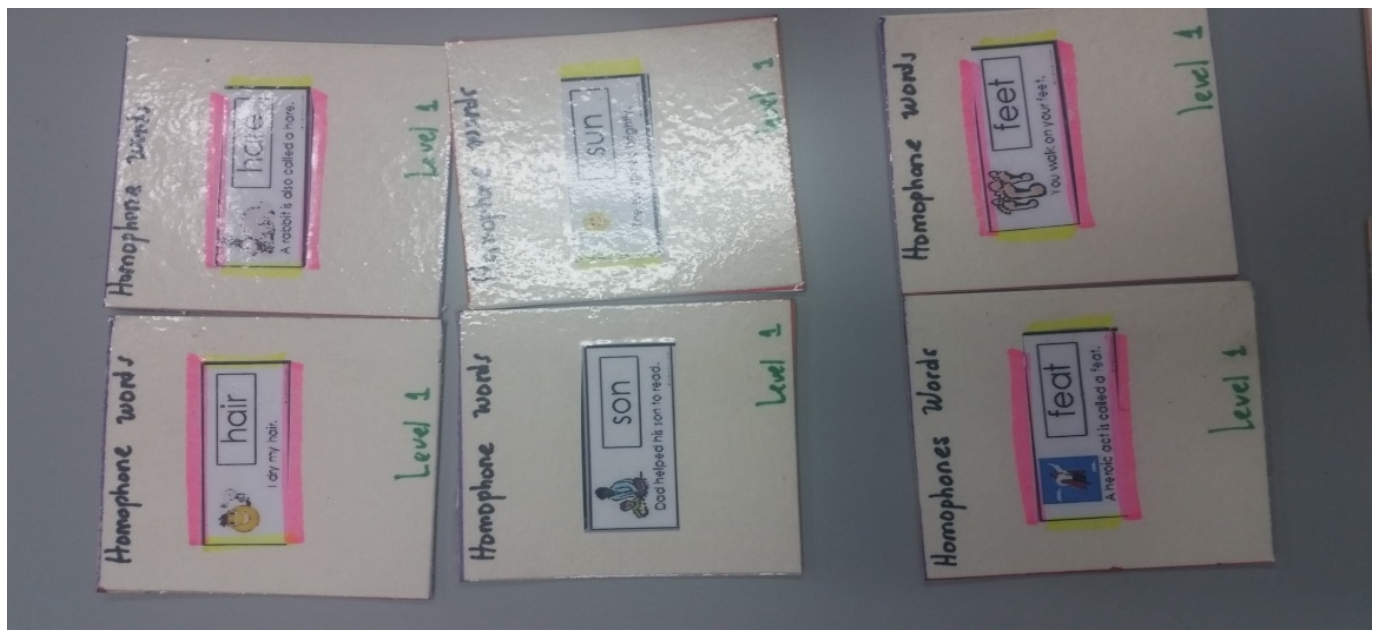

Appendix 10

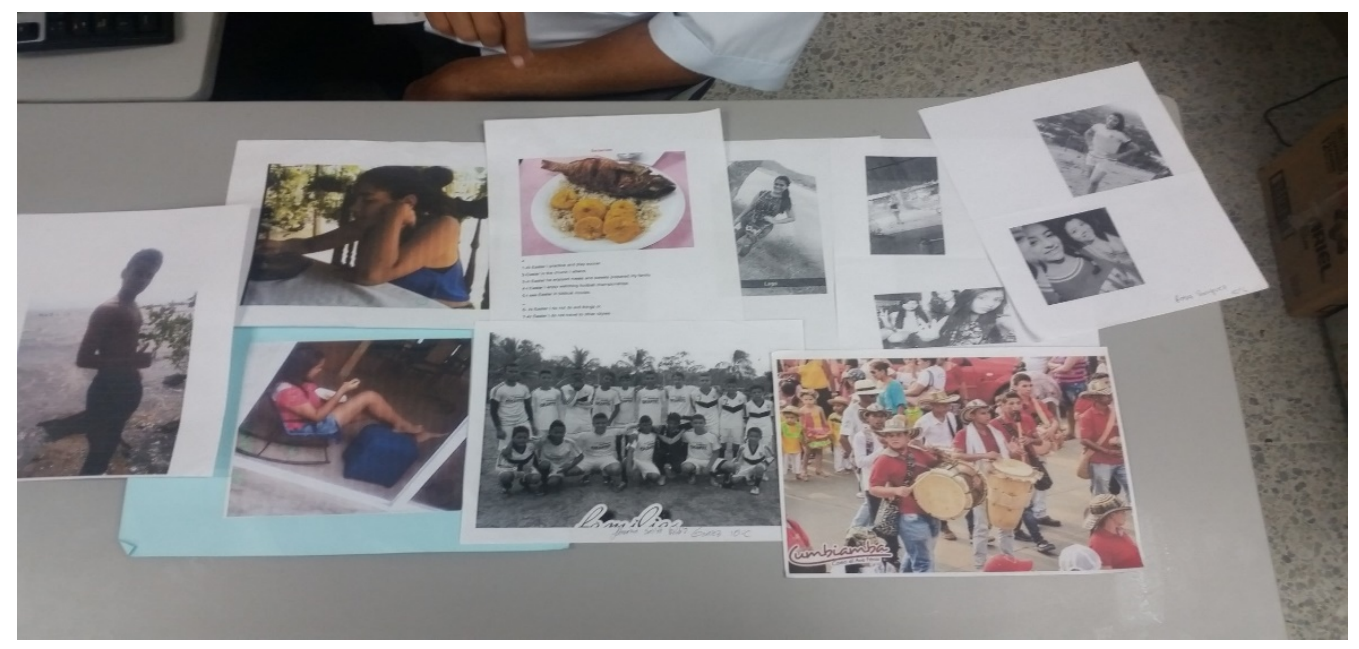

\section{Copyrights}

Copyright for this article is retained by the author(s), with first publication rights granted to the journal.

This is an open-access article distributed under the terms and conditions of the Creative Commons Attribution license (http://creativecommons.org/licenses/by/4.0/). 